\title{
Sticholonche zanclea (PROTOZOA, ACTINOPODA) IN FECAL PELLETS OF COPEPODS AND Euphausia sp. IN BRAZILIAN COASTAL WATERS
}

\author{
ESKINAZI-SANT'ANNA, E. M. \\ Departamento de Oceanografia e Limnologia, Centro de Biociências, Universidade Federal do Rio Grande do Norte, \\ Via costeira, s/n, Praia de Mãe Luiza, CEP 59014-100, Natal, RN, Brazil \\ Correspondence to: Eneida Maria Eskinazi-Sant'Anna, Departamento de Oceanografia e Limnologia, \\ Centro de Biociências, Universidade Federal do Rio Grande do Norte, Via costeira, s/n, Praia de Mãe Luiza, \\ CEP 59014-100, Natal, RN, Brazil, e-mail: eskinazi@ufrnet.br \\ Received March 16, 2005 - Accepted April 12, 2005 - Distributed August 31, 2006
}

(With 8 figures)

\begin{abstract}
Fecal pellets produced by mesozooplanktonic copepods (Centropages velificatus and Paracalanus parvus) and macrozooplanktonic Euphausiacea (Euphausia sp.) were examined using scanning electron microscopy. Fragments of the protozoan Sticholonche zanclea were found in both copepod and in Euphausia sp. fecal pellets, even when the abundance of the protozoan in the water was low. The results suggest that $S$. zanclea is an important food resource for different trophic levels, including meso- and macrozooplankton, in Brazilian coastal waters.
\end{abstract}

Keywords: zooplankton, fecal pellets, feeding, protozoa.

\section{RESUMO}

\section{Sticholonche zanclea (Protozoa, Actinopoda) em pelotas fecais de copépodos e Euphasia sp. em águas costeiras brasileiras}

Pelotas fecais produzidas por copépodos mesozooplanctônicos (Centropages velificatus e Paracalanus parvus) e por Euphasiacea macrozooplanctônico (Euphasia sp) foram examinadas em microscópio eletrônico de varredura. Fragmentos do protozoário Sticholonche zanclea foram encontrados nas pelotas fecais dos copépodos e de Euphasia sp, mesmo quando a abundância do protozoário no ambiente foi bastante reduzida. Os resultados sugerem que $S$. zanclea pode representar um importante recurso alimentar para diferentes níveis tróficos, incluindo meso e macrozooplâncton, em águas costeiras brasileiras.

Palavras-chave: zooplâncton, pelotas fecais, alimentação.

\section{INTRODUCTION}

The role of protozooplankton in the trophic structuring of marine ecosystems has become a key focus in studies of the zooplankton food web (Sherr et al., 1989; Kleppel et al., 1991; Tackx et al., 1995; Kivi et al., 1996; Hwang \& Hetah, 1997). Protozoans are abundant in both nano- and microplankton, and constitute an important food source for many zooplanktonic organisms and fish larvae (Pomeroy, 1974; Turner, 1984a; Porter et al., 1985; Stoecker \& Capuzzo, 1990; Zeldis et al., 2002).
There is little published information on predation on protozoans under natural conditions. Evidence of the ingestion of protozoans comes, mostly, from predation experiments done in situ or in the laboratory (Paffenhöfer et al., 1995), through the use of biomarkers (Kivi \& Setala, 1995; Li et al., 1996), filming (Verity \& Paffenhöfer, 1996), or through identification of hard parts such as loricae and skeletal material in gut contents or in fecal pellets (Conover, 1982).

A previous investigation (Eskinazi-Sant'Anna, 2000) showed that the protozoan $S$. zanclea forms 
part of the natural diet of mesozooplanktonic copepods such as Parvocalanus crassirostris, Paracalanus quasimodo, Temora stylifera, and T. turbinata in the São Sebastião Channel (SSC). The aim of the present study was to verify whether $S$. zanclea is also utilized as a food resource by other zooplankters in the SSC. In order to achieve this, the contents of fecal pellets of the copepods Paracalanus parvus and Centropages velificatus and of the euphausiacean Euphausia sp. were examined under Scanning Electron Microscopy (SEM). These organisms have distinct feeding habitats and body sizes, representing different trophic niches in the SSC.

\section{STUDY AREA}

The São Sebastião Channel is located on the northeast coast of São Paulo State (from $23^{\circ} 41^{\prime} \mathrm{S}$ $45^{\circ} 10^{\prime} \mathrm{W}$ to $23^{\circ} 53^{\prime} \mathrm{S}-45^{\circ} 30^{\prime} \mathrm{W}$ ). The channel is bounded on the west by the slopes of the Serra do Mar, and on the east by São Sebastião Island (Fig. 1). The funnel-shaped channel is curved along its $25 \mathrm{~km}$ length, with the narrowest part
( $2 \mathrm{~km}$ wide) in the center, widening toward both ends to $7.2 \mathrm{~km}$ at the southern entrance and $5.6 \mathrm{~km}$ at the northern entrance. Depths along the channel range from approximately $20 \mathrm{~m}$ at the entrances down to $50 \mathrm{~m}$ in the middle part (Gianesella et al., 1999). Water temperature and salinity vary annually from 18 to ${ }^{\circ} \mathrm{C}$ and 35 to $37 \%$, respectively. Total chlorophyll (chl $a+$ pheopigments) averages $4.3 \mathrm{mg} \mathrm{Chl}-a \mathrm{~m}^{-3}$ and can vary annually from 0.16 to $6.42 \mathrm{mg} \mathrm{Chl}-a \mathrm{~m}^{-3}$ (Gaeta et al., 1995). The temperature in the region is warm year-round, with typical monthly means from $19.5{ }^{\circ} \mathrm{C}$ in winter to $25.5{ }^{\circ} \mathrm{C}$ in summer. Annual precipitation oscillates between 1500 and $2000 \mathrm{~mm}$, with a dry period from June through August and a rainy period from January through March.

\section{MATERIAL AND METHODS}

Sampling campaigns were carried out in January and July 1997, July 1998, and January 1999, at two stations (P1 and P2) in the SSC, Brazil. Surface-water samples $(250 \mathrm{~mL})$ for phytoplankton and protozooplankton analyses

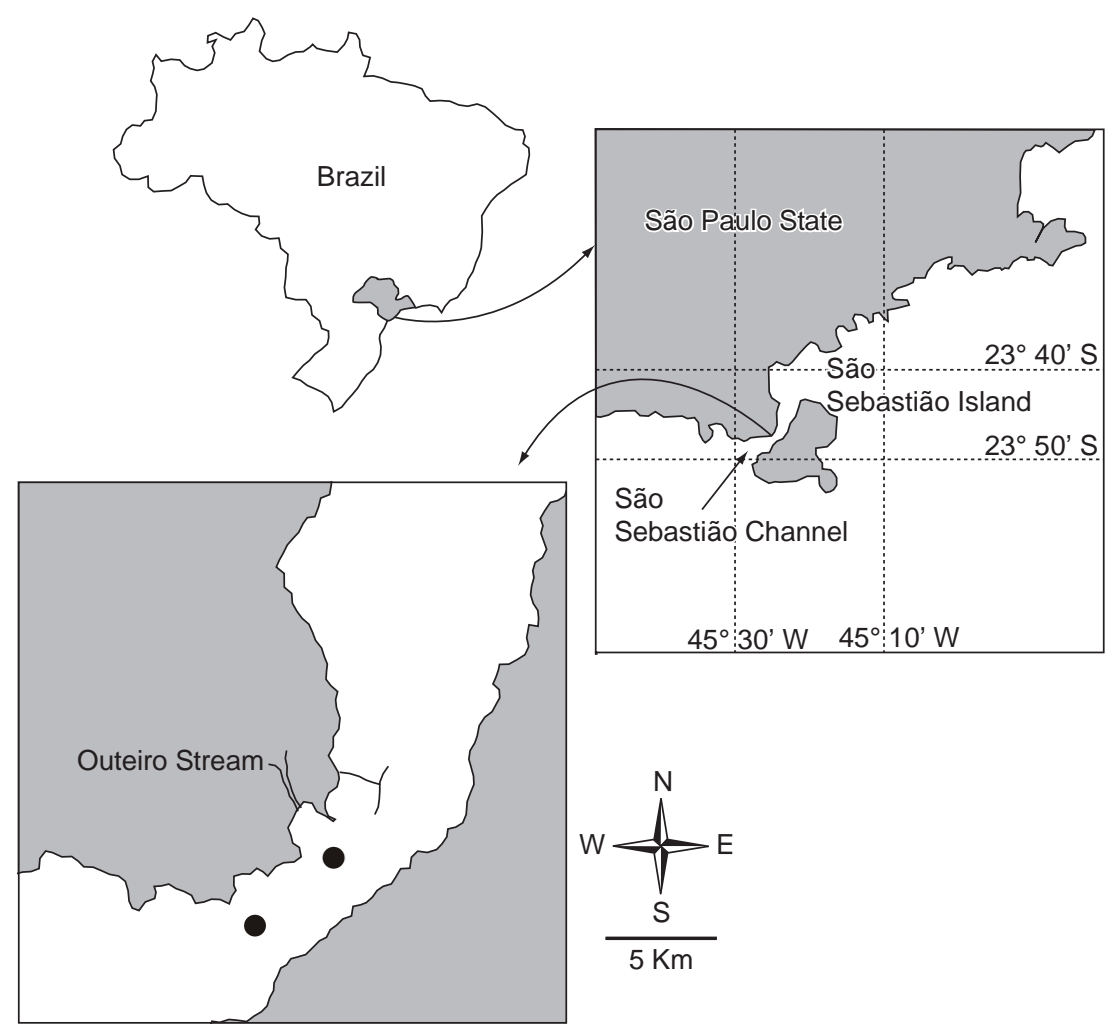

Fig. 1 - São Sebastião Channel, at the Northern coast of São Paulo State, and the position of the sampling points. 
were taken with a van Dorn bottle $(5 \mathrm{~L})$. All samples were fixed with Lugol's solution. Phytoplankton and protozooplankton were enumerated using the inverted microscope method (Lund et al., 1958) under magnifications of 40x, 60x and 100x. Meso and macrozooplankton were collected during 2 min surface tows with a $150 \mu \mathrm{m}$ mesh net. Adult females of the copepods Centropages velificatus and Paracalanus parvus, and individuals of Euphausia sp. were sorted under a WILD M8 stereomicroscope, isolated within 20 min of collection, and transferred to Petri dishes containing collected surface sea water, and then left for 30 to $120 \mathrm{~min}$ to produce fecal pellets. The expelled fecal pellets (15 from $C$. velificatus, 22 from P. parvus, and 25 from Euphausia sp.) were individually removed by pipette and placed in petri dishes containing a mixture of filtered sea water (Nucleopore cellulose acetate membrane filters $20 \mu \mathrm{m}$ ) and $10 \mu \mathrm{m}$ screened surface sea water. The pellets were then left for $24 \mathrm{~h}$ at $24{ }^{\circ} \mathrm{C}$ $\left( \pm 2{ }^{\circ} \mathrm{C}\right)$ for microbial stripping of their peritrophic membranes (Turner, 1984b,c). All pellets were subsequently preserved in $4 \%$ formalin-seawaterglutaraldehyde solution. Ashore, preserved pellets were individually removed by pipette, transferred to Nucleopore filters, and then left to adhere. Filters with attached pellets were washed in distilled water for salt elimination, dehydrated in a graded ethanol series $(50,60,70,80,90,95$, and $100 \%)$, left to dry at room temperature, and then coated with gold. The fecal pellets were examined with a Zeiss DSM-950 Scanning Electron Microscope (SEM).

\section{RESULTS}

Analysis of the fecal pellets of C. velificatus, P. parvus, and Euphausia sp. indicated the presence of $S$. zanclea fragments and remains of diatoms, mainly Chaetoceros sp., Thalassiotrix frauenfeldii, and Thalassionema nitzschioides. Unidentified centric and pennate nanoplanktonic cells $(<20 \mu \mathrm{m})$ were also observed. Fecal pellets of Euphausia sp. contained dinoflagellate remains (Fig. 2) and amorphous material, which was also present in the fecal pellets of C. velificatus (Fig. 3). Overall, the diatom remains observed in the fecal pellets of copepods and Euphausia sp. did not reflect the composition of the available phytoplankton. Phytoplankton abundance in SSC ranged from
25.4 to $717 \times 10^{3}$ cells. $\mathrm{L}^{-1}$. The assemblages were dominated mainly by flagellates and diatoms (mainly Cerataulina pelagica, Leptocylindrus danicus, Skeletonema costatum, and Cylindrotheca closterium). In January 1997, phytoplankton assemblages at station P1 were dominated mainly by flagellates and large diatoms $(>50 \mu \mathrm{m})$, represented by $L$. danicus. At station $\mathrm{P} 2$, the same pattern of phytoplankton assemblage composition was observed, together with the occurrence of C. closterium and Asterionella japonica (Fig. 4).

In fecal pellets of $C$. velificatus and P. parvus, fragments of diatoms (Thalassionema nitzschioides and Thalassiotrix frauenfeldii) and a protozoan (S. zanclea) were observed. Remains of T. nitzschioides and $S$. zanclea were detected in the fecal pellets of Euphausia sp. In July 1997, flagellates comprised almost $90 \%$ of the phytoplankton community at $\mathrm{P} 1$, although in the fecal pellets of all three zooplankters, the main fragments found were of $S$. zanclea and diatoms (mainly T. frauenfeldii).

Identification of S. zanclea fragments was only possible under SEM, which revealed their characteristic ornamentation, consisting of a series of fringes along the spine (Fig. 5). These spines were the only item identified in some pellets (Fig. 6). Fragments of S. zanclea were found in more than $80 \%$ of the pellets of the species studied, during both summer and winter. These were present even when the relative abundance of this protozoan corresponded to less than $10 \%$ of the total microzooplankton in the SSC (Fig. 7), comprising a minimal fraction of the microzooplankton density which ranged from 5 to 101 org.L-1 (Fig. 8).

\section{DISCUSSION}

All the zooplankters examined fed in situ upon S. zanclea. In the fecal pellets of the copepods, the proportion of $S$. zanclea spines was in some cases higher than the proportion of diatom frustules. The same composition pattern was observed in the fecal pellets of Euphausia sp. S. zanclea is apparently an important food resource for different trophic levels in the SSC.

Grassé (1953) described the species S. zanclea as a peculiar organism. It was considered as an intermediary form between heliozoarians and radiolarians, which did not have a defined taxonomic 

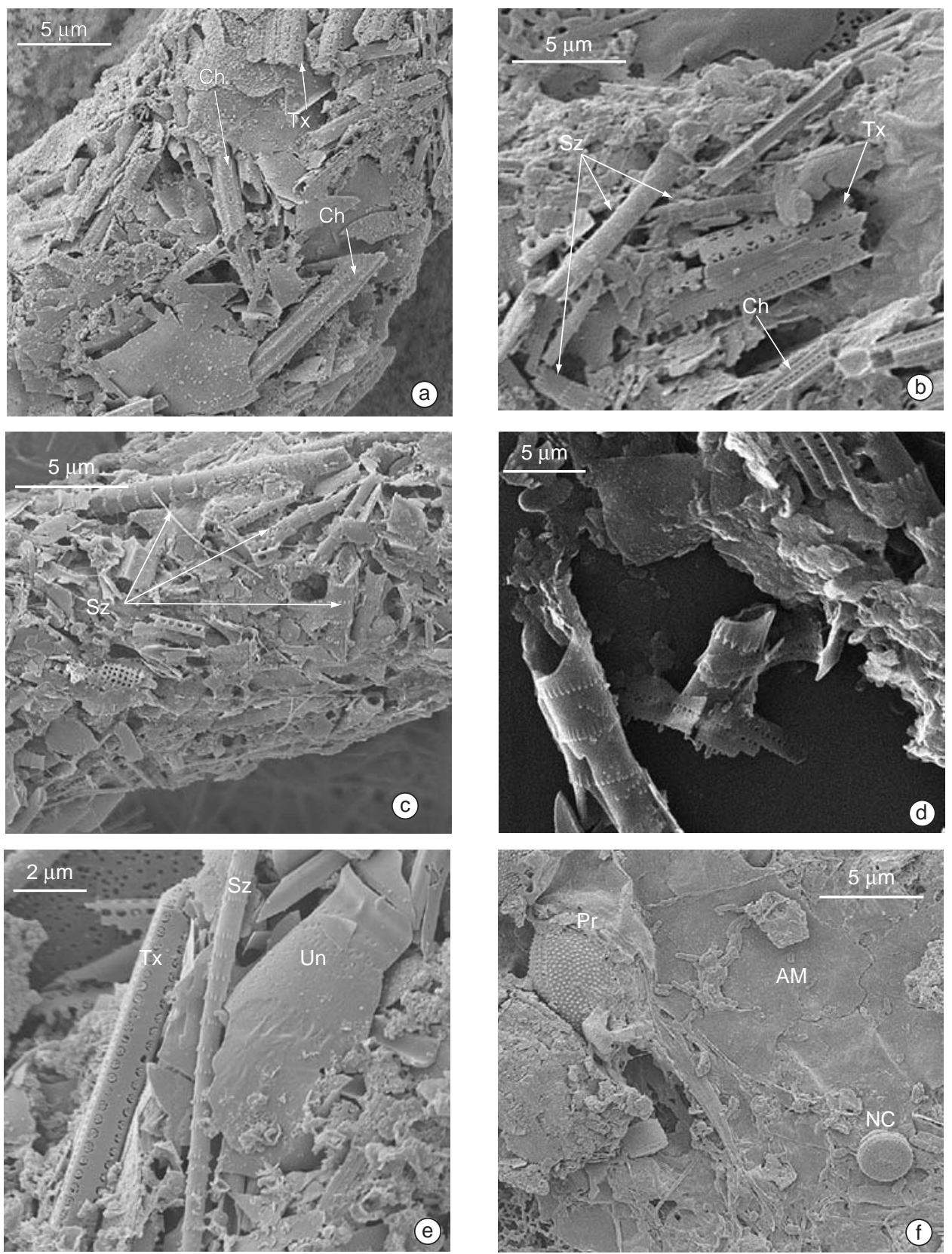

Fig. 2 - Contents of fecal pellets from the copepods C. velificatus (a and b) and P. parvus (c and d) and the Euphasiacea Euphasia $\mathrm{sp}(\mathrm{e}$ and $\mathrm{f}$ ) at $\mathrm{P} 1, \mathrm{Jan} / 97 . \mathrm{Ch}=$ Chaetoceros $\mathrm{sp} ; \mathrm{Tx}=$ Thalassiotrix frauenfeldii $; \mathrm{Sz}=$ Sticholonche zanclea $; \mathrm{AM}=$ Amorphous material; $\mathrm{Pr}=$ Prorocentrum sp; UN = Unknown; NC = Nanoplanktonic cell.

position at that time. S. zanclea is common in the plankton of the Mediterranean Sea (Tregouboff \& Rose, 1957). However, in Brazilian waters its distribution seems to be limited to the southeast coast, since there are no published records of its occurrence in other areas of Brazil.
Diatomswerethemostabundantphytoplankton cells in the feces of the copepods $C$. velificatus and P. parvus, and also of Euphausia sp. Remains of Thalassiotrix frauenfeldii, Thalassionema nitzschioides, and Skeletonema costatum were common in all fecal pellets at all times, suggesting 

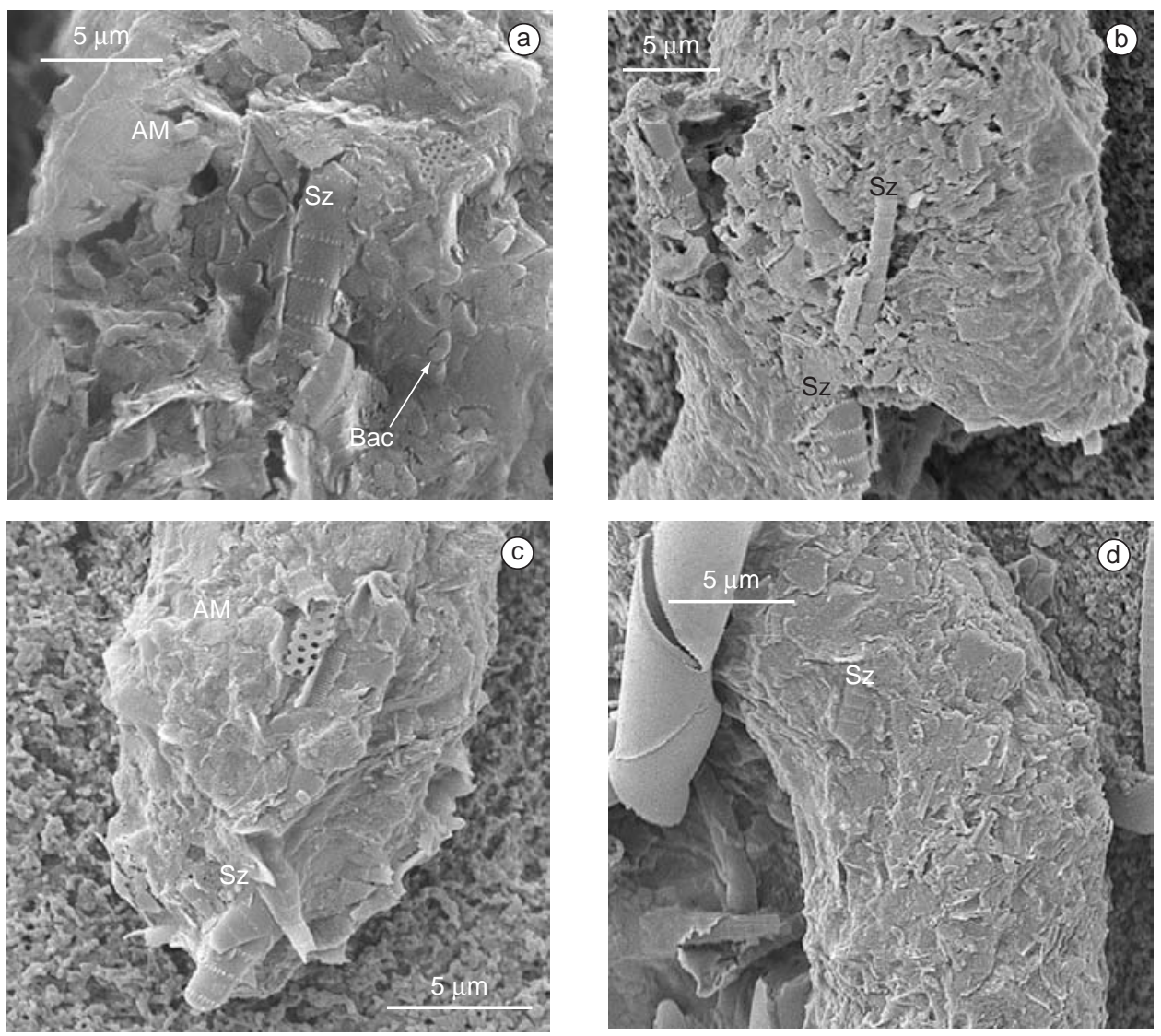

Fig. 3 - Contents of fecal pellets from the copepods C. velificatus (a) and P. parvus (b) and the Euphasiaceae Euphasia sp (c and d) at P2, January/99. Sz = Sticholonche zanclea; $\mathrm{AM}=$ Amorphous material.

that these species are present during all seasonals in the SSC. Also, they seem to be a preferential food source for the meso- and macrozooplankton, even when they are available in low abundance. They may be preferred because of the small size of their cells $(<50 \mu \mathrm{m})$.

Remains of flagellates were not identified in the fecal-pellet contents of either copepods or Euphausia sp. This is surprising, because flagellates may represent a reasonable food source, in view of their small size and ease of digestion because of the lack of a shell or rigid cell walls. Rapid processing of these cells within the digestive tract probably accounts for the difficulty in identifying their fragments in the fecal pellets, even with SEM. Although fecal-pellet analysis is considered a reliable method to determine food preference, there are some limitations to the technique, such as the difficulty of appropriately preserving for identification, particles lacking hard parts or composed only of soft tissue, e.g., flagellates. The amorphous material observed in the fecalpellet contents of $C$. velificatus and $P$. parvus and Euphausia sp. may indicate that these soft-celled organisms were indeed ingested.

Another important observation made through analysis of fecal pellets of copepods and Euphausia sp. was the presence, within a single fecal pellet, of remains of phytoplankton cells and protozoan fragments ranging over two orders of magnitude in their longest dimension. According to Turner (1986), the presence of food fragments of different sizes could be indicative of selective grazing on large particles. Therefore, ingestion of $S$. zanclea by the meso- and macrozooplankton in SSC seems to indicate that these zooplankters are actively selecting this protozoan, because of its size (> $300 \mu \mathrm{m}$ ) and its low abundance in the environment. 


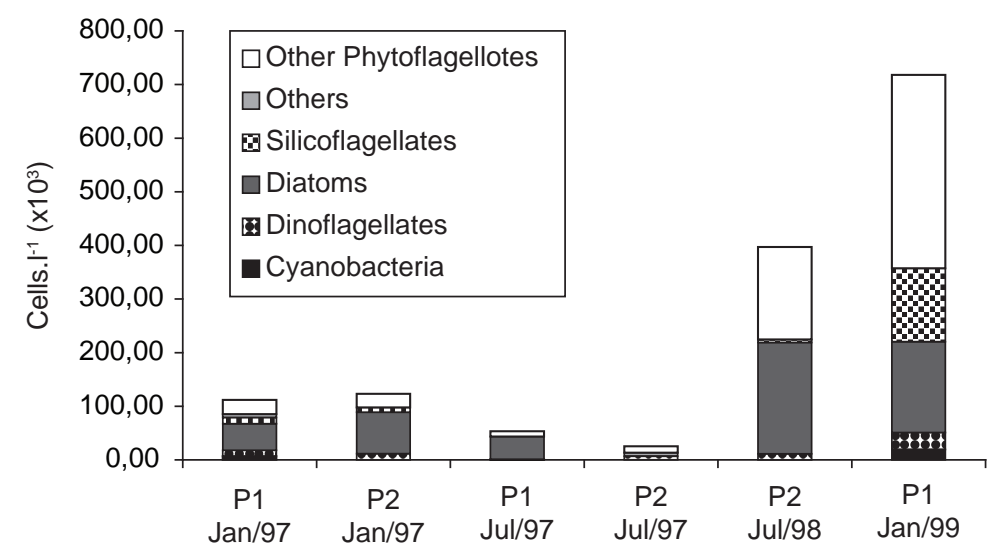

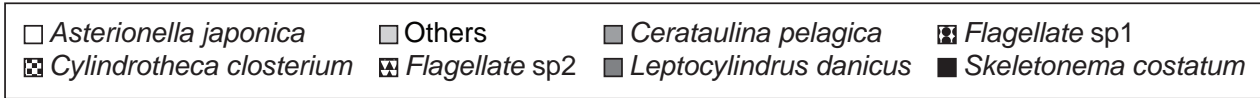

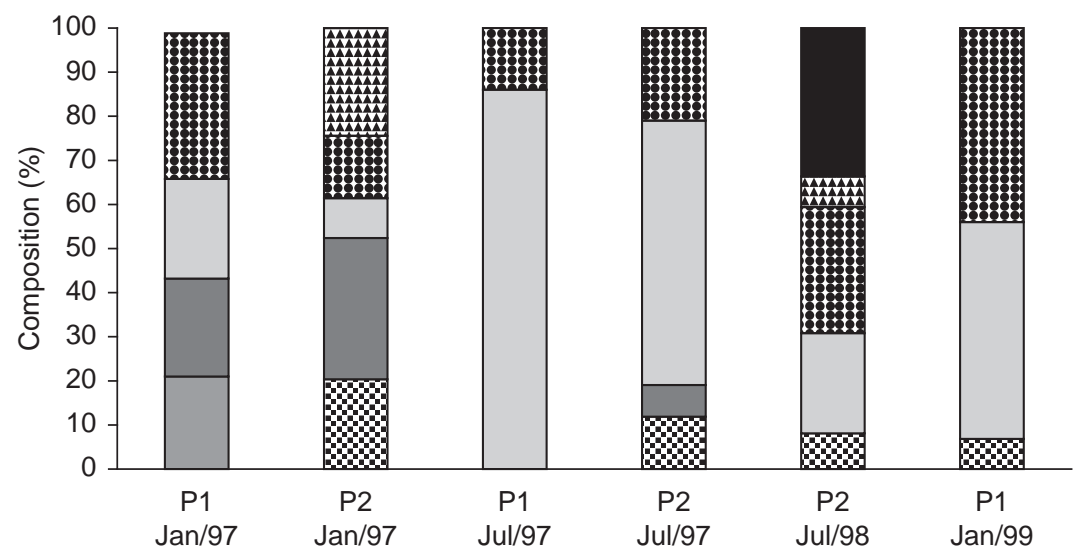

Fig. 4 - Abundance (upper) and composition (lower) of the phytoplankton in the São Sebastião Channel where fecal pellets of zooplankton were collected.
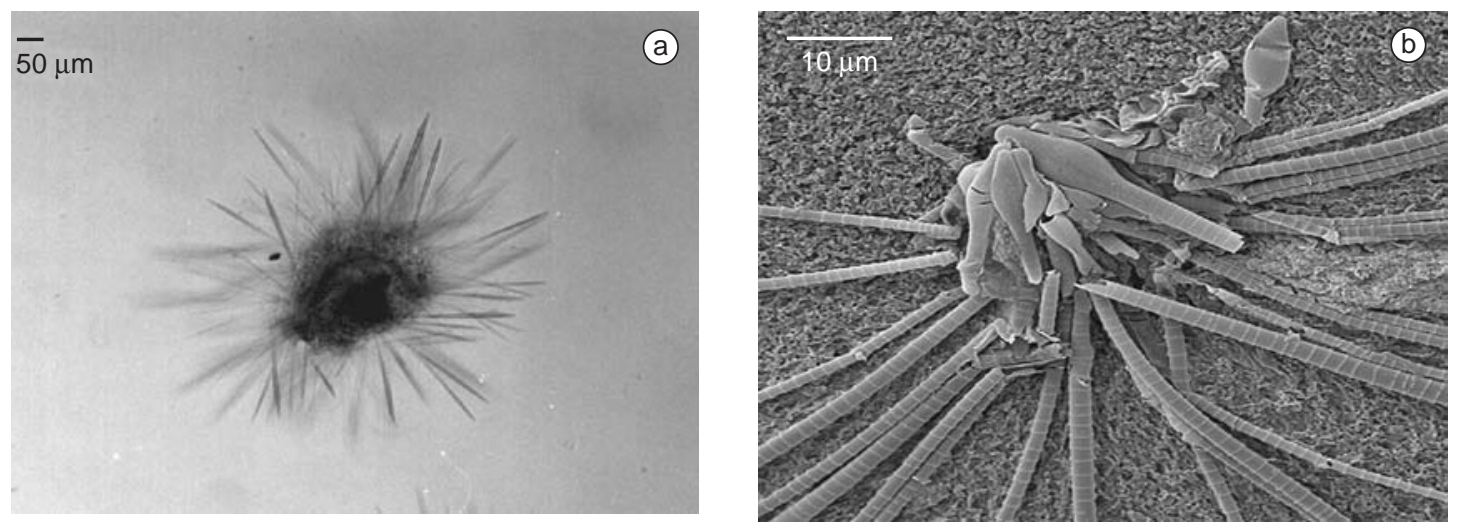

Fig. 5 - Optical (a) and SE microscopy (b) of Sticholonche zanclea collected in the São Sebastião Channel. 

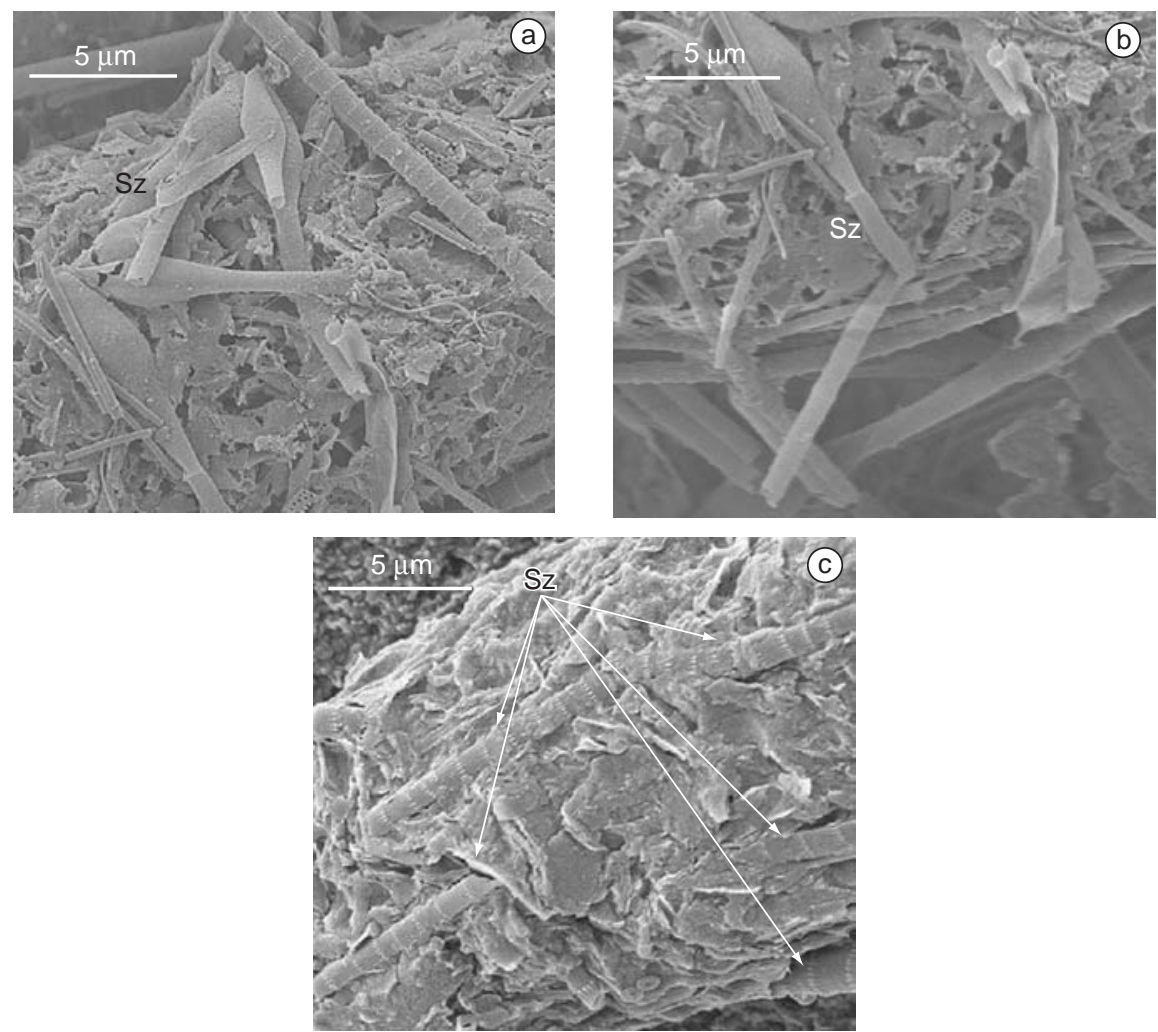

Fig. 6 - Contents of fecal pellets from the copepods C. velificatus (a) and P. parvus (b) and Euphasia sp (c) showing remains of $S$. zanclea $(\mathrm{Sz})$.

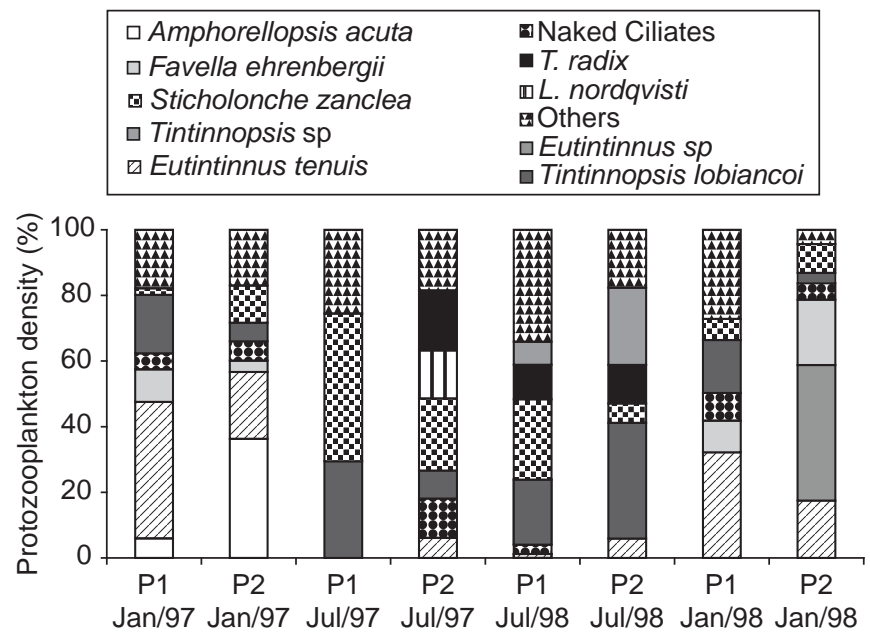

Fig. 7 - Abundance (\%) and composition of the protozooplankton in the SSC.

However, corroboration of this conclusion requires more conclusive experimental treatments.

Predator-prey interactions are important for identifying the links of the planktonic food chains, as well as for interpreting seasonal changes in the structure and species composition of the aquatic community. Protozoans are likely to be an important alternative food resource for 


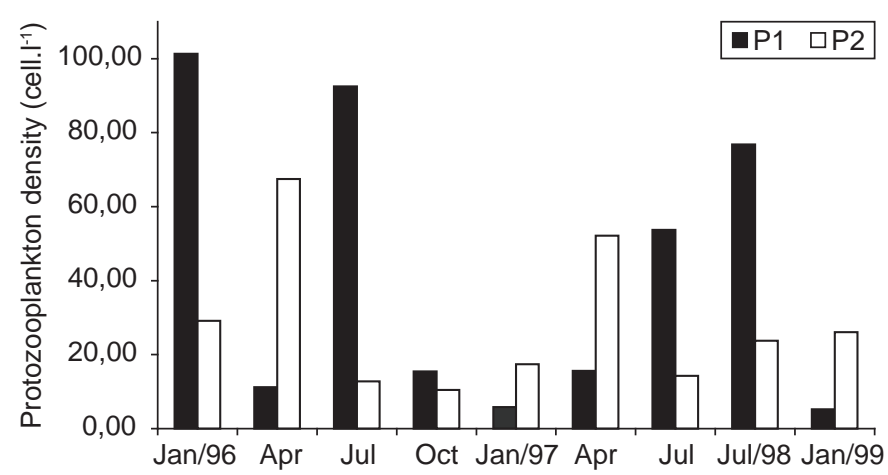

Fig. 8 - Protozooplankton density $\left(\right.$ Cell. $\left.L^{-1}\right)$ in the SSC.

zooplankton, when phytoplankton abundance is low or when phytoplankton quality is reduced (i.e., during periods of nutrient limitation) (Schmidt et al., 1998). The phytoplankton standing-stock in the SSC is similar to levels observed in other tropical coastal areas (Eppley et al., 1978; Webber et al., 1996) and to those reported by Turner \& Tester (1989) and Kleppel et al. (1996) in previous studies on the natural diet of copepods.

Because phytoplankton is available in the $\mathrm{SSC}$, questions that arise are: why is $S$. zanclea predated on by such different zooplanktonic organisms, with different food habits and at high frequency? Also, what would be the competitive advantage for the active capture of a species that is relatively large $(>300 \mu \mathrm{m})$ and rare in the environment?

The search for additional food sources can occur when phytoplankton biomass falls to very low levels, or when drastic changes in phytoplankton composition occur (Smetacek, 1980). The SSC is dominated by Coastal Water $\left(\mathrm{CW}: \mathrm{T}>20^{\circ} \mathrm{C} ; \mathrm{S}>\right.$ $36 \%$ ), but during spring and summer a distinct flow of nutrient-rich, high-salinity, low-temperature water (Central Water from the South Atlantic, CWSA: $\mathrm{T}<20{ }^{\circ} \mathrm{C} ; \mathrm{S}>35 \%$ ) can be detected in the deepest layers. The $\mathrm{CW}$ is superficial, with oligotrophic characteristics, marked by the supremacy of flagellates, which comprise around $70 \%$ of the total number of organisms, and enriched seasonally by intrusion of the CWSA (GianesellaGalvão et al., 1997). Diatoms need high nutrient concentrations, and for this reason are scarce in oligotrophic waters. Because diatoms are the main food item ingested by copepods (Turner, 1991), the quantitative dominance of flagellates in the SSC waters, also confirmed in the present investigation, may be the determining factor for incorporation of heterotrophic food sources, such as the protozoan $S$. zanclea, into the algal diet by the local zooplankton.

Utilization of varied food sources may also be associated with specific micronutrientrequirements, which would help maintain the nutritional status of individuals (Stoecker \& Egloff, 1987; Gifford \& Dagg, 1988). Previous studies (Verity \& Langdon, 1984; Claustre et al., 1988) showed that there are significant differences in the concentration of proteins, carbohydrates, and lipids in planktonic particles. Protozoans are richer in proteins and lipids than diatoms, which may be why they are targets of such intense predation.

Acknowledgments - The author is grateful to the Center of Marine Biology (CEBIMar) of the University of São Paulo, and the Center of Electronic Microscopy (CEMEL) of the Federal University of Minas Gerais for use of their facilities. Financial support was provided by FAPESP (Fundação de Amparo à Pesquisa do Estado de São Paulo).

\section{REFERENCES}

CLAUSTRE, H. et al., 1988, Fatty acid dynamics in phytoplankton and microzooplankton communities during a spring bloom in the coastal Ligurian Sea. Mar. Mic. Food Webs, 3: 51-66.

CONOVER, R. J., 1982, Interrelations between microzooplankton and other plankton organisms. Annals Ins. Oceanog. Paris, 59: 31-46.

EPPLEY, R. W., SAPIENZA, C. \& RENGER, E. H., 1978, Gradients in phytoplankton stocks and nutrients off southern California in 1974-76. Estuar. Coast. Shelf Sci., 7: 291-301.

ESKINAZI-SANT'ANNA, E. M., 2000, Estudo da dieta natural de Parvocalanus crassirostris, Paracalanus quasimodo, Temora stylifera e T. turbinata no Canal de São Sebastião (SP, Brasil). PhD Thesis. Universidade de SãoPaulo, 317p. 
GAETA, S. A. et al., 1995, Size-fractionation of primary production and phytoplankton biomass on inshore waters of the Ubatuba region, Brazil. Publição Esp. Inst. Oceanog. Univ. S. Paulo, 11: 153-162.

GIANESELLA-GALVÃO, S. M. F. et al., 1997, Distribuição do plâncton na região costeira de São Sebastião. Rel. Téc. Inst. Oceanog. S. Paulo, 41: 5-14.

GIANESELLA, S. M. F. et al., 1999, Assessment of plankton community and environmental conditions in São Sebastião Channel prior to the construction of a produced water outfall. Rev. Bras. Oceanog., 47: 29-46.

GIFFORD, D. J. \& DAGG, M. J., 1988, Feeding of the estuarine copepod Acartia tonsa Dana: carnivory vs. herbivory in natural microplankton assemblages. Bull. Mar. Sci., 43: 458-468.

GRASSÉ, P. P., 1953, Traité de Zoologie. Anatomie, Systématique, Biologie. Tome I. Protozoaires: rhizopodes, actinopodes, sporozoaires, cnidosporidies. Fascicule II, Masson et $C^{\text {ie }}$ Éditeurs, Paris: 800-1095.

HWANG, S. J. \& HETAH, R. T., 1997, The distribution of protozoa across a trophic gradient: factors controlling their abundance and importance in the plankton food web. J. Plankton Res., 19: 491-518.

KIVI, K. \& SETALA, O., 1995, Simultaneous measurement of food particle selection and clearance rates of planktonic oligotrich ciliates (Cilophora: Oligotrichina). Mar. Ecol. Prog. Ser., 119: 125-137.

KIVI, K., KUOSA, H. \& TANSKANEN, S., 1996, An experimental study on the role of crustacean and microprotozoan grazers in the planktonic food web. Mar. Ecol. Prog. Ser, 136: 59-68.

KLEPPEL, G. S., HOLLIDAY, D. V. \& PIEPER, R. E., 1991, Trophic interactions between copepods and microplankton: a question about the role of diatoms. Limnol. Oceanog., 36: 172-178.

KLEPPEL, G. S. et al., 1996, Diets of calanoid copepods on the West Florida continental shelf: relationships between food concentration, food composition and feeding activity. Mar. Biol., 127: 209-217.

LI, A., COATS, D. W. \& ADAM, E. J., 1996, Ingestion of fluorescently labeled and phycoerythrin-containing prey by mixotrophic dinoflagellates. Aq. Mic. Ecol., 10: 139-147.

LUND, J. W. G., KIPLING, C. \& CREN, D. L., 1958, The inverted microscope method of estimating algal numbers and the statistical basis of estimations of counting. Hydrobiologia, 11: 143-170.

PAFFENHÖFER, G. A. et al., 1995, Rates of ingestion and their variability between individual copepods: direct observations. J. Plankton Res., 17: 1573-1585.

POMEROY, L. R., 1974, The ocean's food web, a chanching paradigm. Bioscience, 24:499-504.

PORTER, K. G. et al., 1985, Protozoa in planktonic food webs. J. Protozoology, 32: 409-415.

SCHMIDT, K., KÄHLER, P. \& VON BODUGEN, B., 1998, Copepod egg production rates in the Pomeranian Bay (Southern Baltic Sea) as a function of phytoplankton abundance and taxonomic composition. Mar. Ecol. Prog. Ser., 174: 183-195.
SHERR, B. F., SHERR, E. B. \& PEDROS-ALIO, C., 1989, Simultaneous measurement of bacterioplankton and protozoan bacterivory in estuarine water. Mar. Ecol. Prog. Ser., 54: 209-219.

SMETACEK, V. S., 1980, Zooplankton standing stock, copepod faecal pellets and particulate detritus in Kiel Bight. Est. Coast. Shelf Sci., II: 477-490.

STOECKER, D. K. \& EGLOFF, D. A., 1987, Predation by Acartia tonsa Dana on planktonic ciliates and rotifers. J. Exploit. Mar. Biol. Ecol., 110: 53-68.

STOECKER, D. K. \& CAPUZZO, J. M., 1990, Predation on protozoa: its importance to zooplankton. J. Plankton Res., 12: 891-908.

TACKX, M. et al., 1995, Copepod feeding in the Westerschelde and the Gironde. Hydrobiologia, 311: 71-83.

TREGOUBOFF, G. \& ROSE, M., 1957, Manuel de Planctonologie Mediterranénne. Centre nacional de la Recherche Scientifique, Paris, 2v.

TURNER, J. T., 1984a, The feeding ecology of some zooplankters that are important prey items of larval fish. NOAA Technical Report, NMFS 7, 28p.

TURNER, J. T., 1984b, Zooplankton feeding ecology: contents of fecal pellets of the copepods Eucalanus pileatus and Paracalanus quasimodo from continental shelf waters of the Gulf of Mexico. Mar. Ecol. Prog. Ser., 15: 27-46.

TURNER, J. T., 1984c, Zooplankton feeding ecology: contents of fecal pellets of the copepods Temora turbinata and T. stylifera from continental shelf and slope waters near the mouth of the Mississippi River. Mar. Biol., 82: 73-83.

TURNER, J. T., 1986, Zooplankton Feeding Ecology: Contents of Fecal Pellets of the Copepod Undinula vulgaris from Continental Shelf Waters of the Gulf of Mexico. Mar. Ecol., 7: 1-14

TURNER, J. T., 1991, Zooplankton Feeding Ecology: Do CoOccurring Copepods Compete for the Same Food?. Rev. Aquat. Sci., 5: 101-195.

TURNER, J. T. \& TESTER, P. A., 1989, Zooplankton feeding ecology: nonselective grazing by the copepods Acartia tonsa Dana, Centropages velificatus De Oliveira, and Eucalanus pileatus Giesbrecht in the plume of the Mississippi River. J. Exploit. Mar. Biol. Ecol., 126: 21-43.

VERITY, P. G. \& LANGDON, C., 1984, Relationships between lorica volume, carbon, nitrogen and ATP content of tintinnids in Narragansett Bay. J. Plankton Res., 6:859-868.

VERITY, P. G. \& PAFFENHÖFER, G. A., 1996, On assessment of prey ingestion by copepods. J. Plankton Res., 18(10): 1767-1779.

WEBBER, M. K. et al., 1996, Zooplankton distributions and community structure in an area of the south coast shelf of Jamaica. Bull. Mar. Sci., 59: 259-270.

ZELDIS, J. et al., 2002, Omnivory by copepods in the New Zealand Subtropical Frontal Zone. J. Plankton Res., 24: 9-23. 
